\title{
EARLY SLAVONIC SETTLEMENTS AND NAVIGATION AT THE MOUTH OF THE ODRA RIVER
}

\author{
ROMUALD AWSIUK, WŁADYSŁAW FILIPOWIAK*, TOMASZ \\ GOSLAR, ANNA PAZDUR, and MIECZYSKAW F PAZDUR \\ Radiocarbon Laboratory, Silesian Technical University, Gliwice, Poland
}

ABSTRACT. An attempt is presented to establish an absolute chronology of early Slavonic habitation in the region of the mouth of the Odra River up to the Baltic and to find associations with a series of stave boats and dugouts of different levels of technology and navigation. The methodology of the research project is presented and some conclusions of a general nature are drawn from the results already obtained.

\section{INTRODUCTION}

In recent years systematic excavations have resulted in the discovery and exploration of a number of sites associated with early Slavonic occupation at the mouth of the Odra River up to the Baltic, dated by archaeologic methods to the 3rd to 13 th centuries AD. A series of dugouts and stave boats of different ages has also been collected at the National Museum in Szczecin, allowing a detailed study of navigation for a period of $>1000 \mathrm{yr}$. A joint research project has been undertaken to establish a precise absolute chronology of habitation in this area and to find associations with ${ }^{14} \mathrm{C}$-dated boats of different levels of technology and navigation.

\section{METHODOLOGY}

Systematic studies of the chronology of habitation at the mouth of the Odra River are based on a well-stratified settlement with more than $20 \mathrm{cul}$ tural layers in Wolin, which is regarded to be a reference site for this area (Filipowiak, 1973). Six other settlements, situated south and east of Wolin, were also selected for dating to obtain a more complete picture both in space and time. Because of numerous samples and limited laboratory capacity, we decided to concentrate our efforts on a single trench in Site 1 at Wolin in the first stage of our study. Four units of the trench were selected prior to dating, based on stratigraphic, lithologic, morphologic, and chronologic characteristics. Each unit is represented by 2 to 6 samples of various origin, including short-lived organic materials (moss, hazelnuts, charred millet grains) and charcoal. Samples were collected from both horizontal and vertical locations of the units in order to obtain a reliable and self-checking system of ${ }^{14} \mathrm{C}$ dates. This would also exclude or at least minimize the effects of reworking of older sediments ("anthropogenic bioturbation," cf Willkomm, 1983), the ageing of ${ }^{14} \mathrm{C}$ dates resulting from the repeated use of some materials (Filipowiak, 1973, p 76, fig 45), bioturbation caused by small animals, physical and chemical contamination, etc.

The study of the chronology of navigation presents incomparably greater difficulties because it must be based, in fact, on objects loosely connected with the cultural and stratigraphic context. Moreover, the boats studied do not form a continuous chronologic sequence and should be regarded as rather isolated time markers with complicated internal struc-

* National Museum, Szczecin, Poland 
tures resulting from a variety of materials used during their construction and exploitation. Few objects, then, have been selected for ${ }^{14} \mathrm{C}$ dating from an ample collection of stave boats and dugouts gathered at the National Museum in Szczecin. Four stave boats were carefully dated, including four types of basic elements of stave boats, $i e$, wood from the keel, stave and tree nails, and moss or animal hair used to seal the boat. Samples of staves, tree nails and moss would be either of primary (construction) or secondary (repairing) origin; both types of samples were chosen for dating when available. This basic series was implemented by single ${ }^{14} \mathrm{C}$ dates from three dugouts.

\section{RESULTS}

\section{The Wolin Reference Site: Site 1, Trench 6}

Seventeen layers of continuous occupation were distinguished with three half-dugouts at the base, below the oldest layer, no. XVII. Four units were selected for detailed dating: 1) half-dugout no. 3; 2) half-dugout no. 2; 3) layer no. XVI; 4) cultural layers, XV to X. All ${ }^{14} \mathrm{C}$ measurements corrected for isotopic fractionation are presented in Table $1 . \delta^{13} \mathrm{C}$ values range from $-11 \% 0$ vs PDB for charred millet grains, to $-31 \%$ for moss samples, leading to age corrections from +220 to $-100 \mathrm{yr}$, respectively. Interesting to observe is systematic increase of $\delta^{13} \mathrm{C}$ for moss samples from layers $\mathrm{X}$ to XVI with increasing depth (and age). ${ }^{14} \mathrm{C}$ dates of moss samples from the unit no. 4 (layers $\mathrm{X}$ to XV) indicate clearly the two distinct phases of habitation within this unit. Two clearly outlying dates are found within this series. The first one, Gd-3048, $1150 \pm 35 \mathrm{BP}$, obtained on well-preserved hazel-

TABLE 1

${ }^{14} \mathrm{C}$ dates for the Wolin reference site

\begin{tabular}{llccc}
\hline Unit & \multicolumn{1}{c}{ Material } & $\begin{array}{c}\text { Gd- } \\
\text { no. }\end{array}$ & $\begin{array}{c}{ }^{14} \mathrm{C} \text { age } \\
\text { conv BP }\end{array}$ & $\begin{array}{c}\delta^{13} \mathrm{C} \\
\% \text { vs PDB }\end{array}$ \\
\hline Layer X & Moss & 1779 & $1030 \pm 40$ & -30.9 \\
Layer XI & Moss & 2253 & $1040 \pm 60$ & -30.4 \\
Layer XII & Moss & 2334 & $1440 \pm 60$ & -30.0 \\
Layer XIII & Moss & 1850 & $1040 \pm 50$ & -28.5 \\
Layer XIV & Moss & 2335 & $1190 \pm 60$ & -29.0 \\
Layer XV & Moss & 2267 & $1200 \pm 60$ & -28.3 \\
Layer XVI & Charcoal & 1711 & $1340 \pm 50$ & -26.2 \\
& Charcoal & 3039 & $1290 \pm 35$ & -25.2 \\
& Charcoal & 1714 & $1340 \pm 60$ & -25.2 \\
Half- & Hazelnuts & 3048 & $1150 \pm 35$ & -28.0 \\
dugout & Hazelnuts & 2216 & $1290 \pm 70$ & -27.8 \\
no. 2 & & & & $-25 *$ \\
Half- & Charcoal & 1666 & $1570 \pm 50$ & -25.0 \\
dugout & Moss & 2218 & $1310 \pm 110$ & -11.3 \\
no. 3 & & & & -12.4 \\
& Millet grains & 1709 & $1390 \pm 40$ & -13.1 \\
& Millet grains & 1710 & $1370 \pm 50$ & -25.7 \\
\hline
\end{tabular}

* Estimated value 
nuts from layer XVI, is significantly younger than the other four dates from this unit. We believe that this is caused by small animals carrying the hazelnuts to this layer from the top. The second outlying date, Gd-2334, $1440 \pm$ $60 \mathrm{BP}$, obtained on a moss sample from layer XII, is significantly older than the other dates from this unit. It is difficult to explain why; we can only suspect the repeated use of older material, or, what seems more probable, local reworking of the sediment.

Three effects were observed after the application of the Stuiver (1982) calibration curve to these data: 1) a small but noticeable reduction of the scatter of dates within each dated unit; 2) a practically unchanged position of the outlying dates; 3 ) the appearance of multiple calibrated dates, which in most cases cannot be resolved due to large dating errors and must be then regarded as time intervals. Calibrated ${ }^{14} \mathrm{C}$ dates are shown in Figure 1 together with the resulting chronology of the site.

\section{Other Settlements}

Six other settlements situated south and east of Wolin, which, on the basis of associated cultural material, had been expected to correspond to different phases of the development of the Wolin settlement, were chosen for dating to reconstruct the chronology of habitation in this area. ${ }^{14} \mathrm{C}$ dates are presented in Table 2 and summarized in the central section of Figure 2.

\section{Navigation}

${ }^{14} \mathrm{C}$ dates obtained for four stave boats and three dugouts are listed in Table 3 and summarized in the right hand section of Figure 2. Wood samples from keels were collected as sections containing 20 to 30 outermost

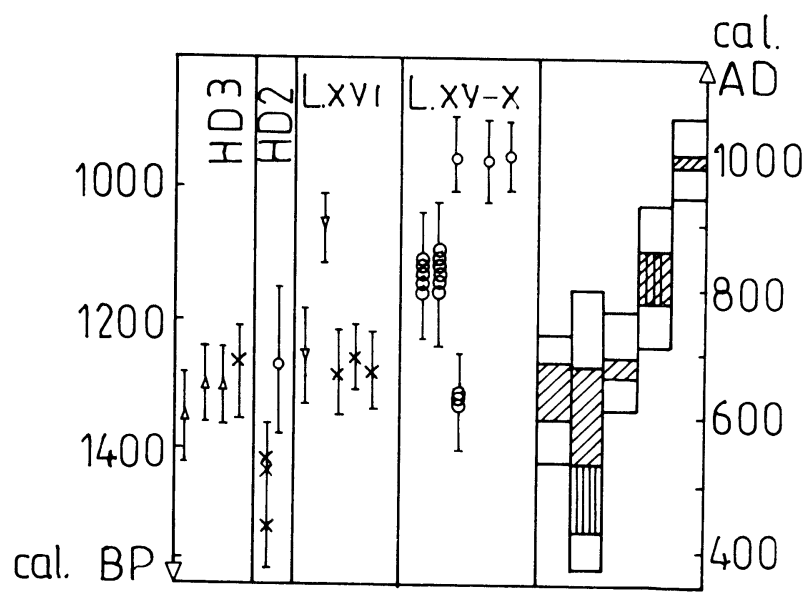

Fig $1 .{ }^{14} \mathrm{C}$ dates for the Wolin reference site calibrated according to Stuiver (1982) and the resulting chronology of habitation. Materials dated: $0-$ moss, $x-$ charcoal, $\nabla-$ hazelnuts, $\triangle$-charred millet grains. Units: HD3-half-dugout no. 3, HD2-half-dugout no. 2, L.XVI-lowermost cultural layer no. XVI, L.XV-X-cultural layers from XV to X. Dashed areas: skew-time intervals determined by ${ }^{14} \mathrm{C}$ dates of different samples; vertical-time resulting from multiple calibrated dates. Open area-limits of dating errors $(1 \sigma)$. 
TABLE 2

${ }^{14} \mathrm{C}$ dates of settlements in the vicinity of the Wolin village

\begin{tabular}{llccc}
\hline Site & \multicolumn{1}{c}{ Material } & $\begin{array}{c}\text { Gd- } \\
\text { no. }\end{array}$ & $\begin{array}{c}{ }^{14} \text { Cage } \\
\text { conv BP }\end{array}$ & $\begin{array}{c}\delta^{13} \mathrm{C} \\
\% \text { vs PDB }\end{array}$ \\
\hline Lubieszewo & Charred grains & 2276 & $1750 \pm 50$ & -24.1 \\
Lubieszewo & Charred grains & 2279 & $1830 \pm 60$ & -22.6 \\
Lubieszewo & Charcoal & 3083 & $1630 \pm 50$ & -26.2 \\
Lubieszewo & Charcoal & 3086 & $1490 \pm 40$ & -26.8 \\
Xobżany & Charcoal & 3084 & $1800 \pm 50$ & -25.9 \\
Kobżany & Charcoal & 1788 & $1600 \pm 50$ & -25.4 \\
Derczewo & Charcoal & 3089 & $1090 \pm 50$ & -26.1 \\
Derczewo & Charcoal & 3087 & $1150 \pm 35$ & -25.6 \\
Derczewo & Charcoal & 1819 & $1080 \pm 60$ & -25.0 \\
Dzicdzice & Charcoal & 3090 & $1130 \pm 35$ & -25.4 \\
Dziedzice & Charcoal & 1790 & $920 \pm 40$ & -25.8 \\
Debczyno & Charcoal & 2275 & $1330 \pm 80$ & -25.8 \\
Gardziec & Charcoal & 1792 & $960 \pm 40$ & -25.8 \\
\hline
\end{tabular}

tree rings, but in spite of this, two ${ }^{14} \mathrm{C}$ dates (for the Wolin town wreck and the Szczecin Rynek boat) are significantly older than dates from other samples from these objects. Nothing can be said about the possible ageing of wood samples from staves and tree nails before detailed dendrochronologic analysis is completed. ${ }^{14} \mathrm{C}$ dates obtained for both the Szczecin Rynek

cal.

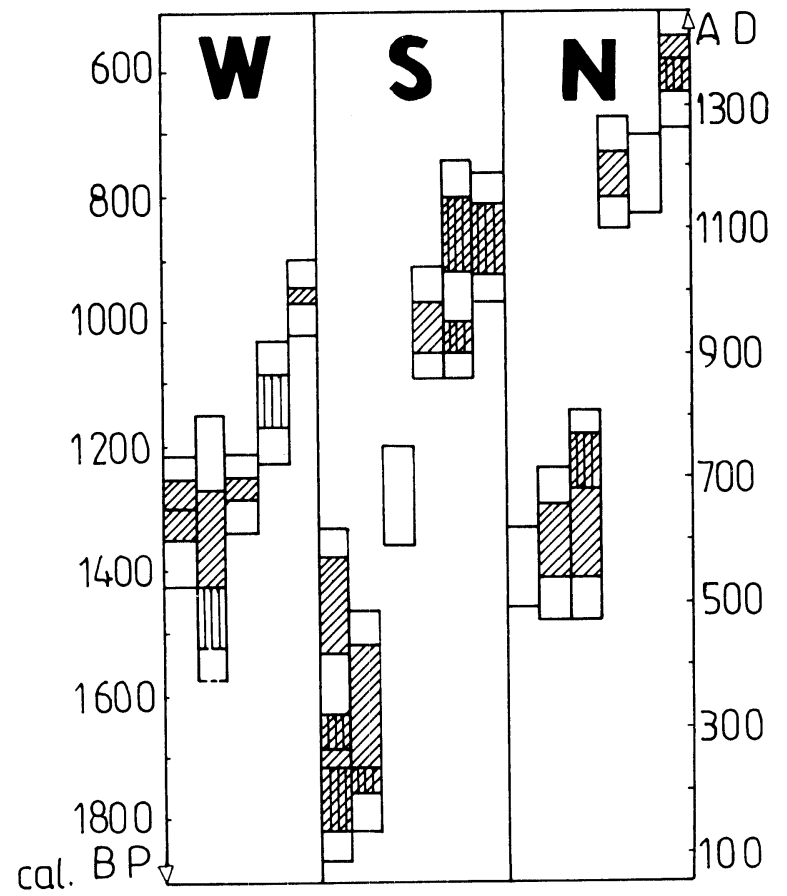

Fig 2. Summarized chronology of early Slavonic habitation and navigation at the mouth of the Odra River. W-Wolin site, S-other settlements, N-navigation. Dashed and open areas as in Fig 1. 
boat and the Kamień Pomorski Żółcino wreck form a consistent series, and no systematic shift is seen between samples of wood (besides Gd-2237) and moss. Moreover, the results do not show the expected age difference between samples thought to be of primary and secondary origin. We should conclude, therefore, that the time elapsed from the construction of these boats to their repair was not longer than the age error, $i e$, some score of years. The duration of the exploitation of the boats studied seems to be of the same order.

\section{CONCLUSIONS}

The summarized chronology based on up-to-date results shown in Figure 2 reveals significant gaps between the three types of sites. The continuous chronology of the Wolin site, covering more than five centuries, seems to be well established in spite of a few outlying results, but the other two series of dates need more samples to fill the gaps. It is interesting to note the persistence of a rather primitive technology of the dugout boats marked by the ${ }^{14} \mathrm{C}$ dates from Table 3 .

This study leads to the following conclusions regarding our dating methodology, itself: 1) reliable dating of settlements with long-lasting intensive habitation should be based on multiple dates obtained from series of samples carefully selected from well-defined stratigraphic or chronologic units; 2) selected samples should provide a self-check of dates for each dated unit; 3) in the construction of the chronology of successive units, time intervals determined by sets of ${ }^{14} \mathrm{C}$ dates obtained from series of different samples after rejection of outliers, seem to be more appropriate than the corresponding mean values of age.

A second stage of this project is now started, which will include TL,

TABLE 3

${ }^{14} \mathrm{C}$ dates for stave boats and dugouts

\begin{tabular}{|c|c|c|c|c|c|c|}
\hline Site & Sample & Material & Origin & $\begin{array}{l}\text { Gd- } \\
\text { no. }\end{array}$ & $\begin{array}{l}{ }^{14} \mathrm{C} \text { age } \\
\text { conv BP }\end{array}$ & $\begin{array}{c}\delta^{13} \mathrm{C} \\
00 \text { vs PDB }\end{array}$ \\
\hline \multirow[t]{2}{*}{ Wolin village } & Keel & Wood & $\mathrm{P} *$ & 2300 & $1540 \pm 50$ & -27.0 \\
\hline & Tree nail & Wood & $\mathrm{P}$ & 2281 & $1280 \pm 40$ & -28.2 \\
\hline \multirow[t]{5}{*}{ Szczecin Rynek } & Keel & Wood & $\mathbf{P}$ & 2237 & $1540 \pm 70$ & -26.8 \\
\hline & Tree nail & Wood & $\mathrm{P}$ & 2239 & $1360 \pm 60$ & -26.0 \\
\hline & Stave & Wood & $\mathrm{P}$ & 2238 & $1390 \pm 60$ & -26.0 \\
\hline & Sealing & Moss & $\mathrm{S}^{* *}$ & 2236 & $1410 \pm 70$ & -32.8 \\
\hline & Sealing & Moss & $\mathrm{P}$ & 2240 & $1180 \pm 70$ & -30.0 \\
\hline \multirow[t]{6}{*}{ Kamień Pom Żółcino } & Keel & Wood & $\mathrm{P}$ & 2282 & $840 \pm 60$ & -26.0 \\
\hline & Tree nail & Wood & $\mathrm{P}$ & 2291 & $820 \pm 60$ & -26.0 \\
\hline & Stave & Wood & $\mathrm{P}$ & 3121 & $960 \pm 35$ & -26.8 \\
\hline & Sealing & Moss & $\mathrm{P}$ & 1829 & $880 \pm 40$ & -33.8 \\
\hline & Sealing & Moss & $\mathrm{P}$ & 2312 & $890 \pm 60$ & -32.6 \\
\hline & Sealing & Moss & S & 2285 & $810 \pm 60$ & -32.0 \\
\hline \multirow[t]{3}{*}{ Wolin polder } & Sealing & Moss & $\mathbf{P}$ & 2308 & $520 \pm 50$ & -30.0 \\
\hline & Sealing & Hair & $\mathbf{P}$ & 1837 & $520 \pm 40$ & -23.5 \\
\hline & Sealing & Moss & $S$ & 2307 & $580 \pm 60$ & -30.0 \\
\hline Kamień Pom Cathedral & Dugout & Wood & & 2309 & $1490 \pm 60$ & -25.0 \\
\hline Kamień Pom Swiniec & Dugout & Wood & & 2311 & $770 \pm 60$ & -29.5 \\
\hline Szczecin & Dugout & Wood & & 2313 & $<150$ & - \\
\hline
\end{tabular}

$* \mathrm{P}=$ primary (construction)

$* * \mathrm{~S}=$ secondary (repair) 
${ }^{14} \mathrm{C}$, and dendrochronologic dates of other trenches on the Wolin reference site.

\section{REFERENCES}

Filipowiak, W, 1973, Wyspa Wolin w prahistorii i we wczesnym średniowieczu: Inst Zachodniopomorski, Prace, v 45, p 37-137.

Stuiver, M, 1982, A high-precision calibration of the AD radiocarbon timescale: Radiocarbon,

v 24, p 1-26.
Willkomm, H, 1983, The reliability of archaeologic interpretation of ${ }^{14} \mathrm{C}$ dates, in Stuiver, $\mathrm{M}$, and Kra, RS, eds, Internatl ${ }^{14} \mathrm{C}$ conf, $11 \mathrm{ch}$, Proc: Radiocarbon, v 25, no. 2, p 645-646. 